\title{
The evolution of EU financial
}

services law

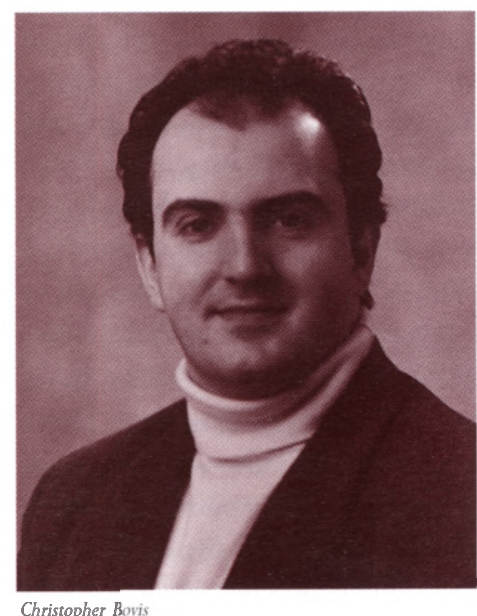

Christopher Bovis

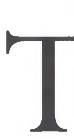

The Treaty of Rome establishing the European Community as amended by the Single European Act and the Maastricht Treaty on Europeàn Union have intended to create an internal market encompassing a whole range of services including financial services such as banking, insurance and the markets in stocks, securities and related products. Primary Community legislation stipulates the parameters of the principle of free movement of capital as an essential element for the creation of the common market. The Court of Justice has recognised the free movement of payments as an additional freedom to the four fundamental freedoms of the European Community.

The services sectors have seen a dramatic expansion in recent years in contrast with manufacturing, which has reached overcapacity levels throughout the world. Although the provision of services could be regarded as an ancillary activity to the manufacturing industry, contemporary growth patterns support the view that services have acquired a more autonomous dimension in economic orders. A shift, in terms of relative importance with reference to a country's GDP, from traditional manufacturing to services has occurred.

Although the European integration process achieved considerable progress in liberalising the services sector in the common market, the goals set out in the Treaty had still not been fully achieved by 1985 . In that year the European Commission published the White Paper for the Completion of the Internal Market, calling for a new impetus to integration. The aim was to integrate national economies into a single market by the end of 1992. The whitc paper programme was incorporated into the Community legal order in 1986 by virtue of the Single European Act amending the EC treaties, which defined the internal market as:

'an area without internal frontiers in which the free movement of goods, services, persons and capital is ensured'.

The white paper made the point that a common market for goods was already to a large extent in place and that it was important to make similar progress in the area of services, particularly financial services, in the light of their vital role in the European economy.

\section{INTEGRATION OF THE BANKING SECTOR}

The first banking co-ordination directive (Directive 77/780) was adopted in 1977 and achieved three main goals. The first was to abolish most of the obstacles to freedom of establishment for banks and other credit institutions within the common market. The second goal consisted in laying down common standards for granting banking licences in European member states. Finally, the third and most important goal was to introduce the basic principle of home country control, where home regulatory and supervisory authorities have responsibility for the activities of banking institutions operating in different member states.

The latter principle indicated advanced co-operation between domestic supervisory authorities in an attempt to avoid duplication of regulation and to reduce unnecessary bureaucracy. The first banking directive was a genuine legal instrument which intended to harmonise the divergent field of banking and related services in the common market and achieve a common platform of operational parameters for the industry.

However a number of obstacles still needed to be removed before a genuinely unified Community banking market could become fully operational. The most important ones reflected the bureaucratic and somewhat protectionist environment of different member states. Banks or credit institutions still had to obtain prior authorisation from 11 different supervisory authorities to set up branches in other member states. On the other hand, it was impossible to offer banking services across the frontiers in some member states, a fact which epitomised the closed and highly segmented domestic banking sectors across Europe. Finally, a problem inherent to the directive created some degree of legal uncertainty; banking activities had not been precisely defined in the directive itself.

\section{FURTHER BANKING DIRECTIVES}

As a response to the above shortcomings, the second banking co-ordination directive (Directive 89/646), adopted in 1989, abolished all these barriers. It consolidated the principle of a single banking licence, valid throughout the European 
Community, authorising a bank or credit institution to operate anywhere in the common market either through branches or directly. National supervisory authorities were obliged to recognise licences issued in other member states. It also set out a list of banking activities, including not only the main traditional services but also some that were new for certain member states, such as trading in securities. Finally, it laid down a minimum capital requirement of ECU $5 \mathrm{~m}$ in order to found a new bank. Supervisory rules were also introduced covering, among other things, internal management and audit systems.

Further legislation was needed to ensure equal competition between banks and other credit institutions and to forestall a migration of banks to countries with less strict supervision. Consumer protection considerations (resulting from the integration of the banking sector in Europe) were of paramount importance. To eliminate uncertainty and establish a concrete basis for European banking services, there were directives defining the bank's own funds (Directive 89/299) and forming the numerator of a solvency ratio applicable to banking and credit institutions operating within the common market (Directive 89/647).

\section{EUROPEAN BANKING DIRECTIVES}

Directive $73 / 183$ on the abolition of restrictions on freedom of establishment and freedom to provide services in respect of selfemployed activities of banks and other financial institutions (OJ 1973 L194/1)

Directive $77 / 780$ on the co-ordination of the laws, regulations and administrative provisions relating to the taking up and pursuit of the business of credit institutions (OJ 1977 L322/30)

Directive $89 / 646$ on the co-ordination of laws, regulations and administrative provisions relating to the taking up and pursuit of the business of credit institutions and amending Directive 771780 (OJ 1986 L386/1)

Directive 94/19 on deposit guarantee schemes (OJ 1994 L135/5)

Directive $89 / 299$ on the own funds of credit institutions (OJ 1989 L124/16)

Directive 89/647 on a solvency ratio for credit institutions (OJ 1989 L386/14)

Directive $91 / 31$ adapting the technical definition of 'multilateral development banks' in Directive $89 / 647$ on a solvency ratio for credit institutions (OJ $1991 \mathrm{~L} 17 / 20$ )

Directive $92 / 30$ on the supervision of credit institutions on a consolidated basis (OJ 1992 L110/42)

Directive $86 / 635$ on the annual accounts and consolidated accounts of banks and other financial institutions (OJ 1986 L372/1)

Directive $89 / 117$ on the obligations of branches established in a member state of credit institutions and financial institutions having their head offices outside that member state regarding the publication of annual accounting documents (OJ 1989 L44/40)

Directive $91 / 308$ on prevention of the use of the financial system for the purpose of money laundering (OJ 1991 L166/77)

Directive $92 / 121$ on the monitoring and control of large exposures of credit institutions (OJ 1992 L29/1)

The own funds directive complements the solvency ratio directive which set high capital adequacy standards in the industry. The directive applies a solvency ratio (8\%) between assets and off-balance sheet items, which are adjusted to reflect different degrees of risk, and own funds available to cover those risks. The bank's own funds have been divided into two-tier systems, which are supposed to cover the bank's risks on an equal basis; for example, own funds in the first tier include capital reserves and reserves for general banking risks which must represent at least $4 \%$ of the solvency ratio. Every other item must fall within the remaining $4 \%$.

\section{Consumer protection}

The protection of the consumer and the general public were the main objectives behind two recommendations relating to the protection of depositors' interests and to limiting the size of exposure risks undertaken by credit institutions. The uniform control of large exposures of credit institutions and the monitoring of their risk concentrations were the subjects of the large exposure directive (Directive 92/121), which defined large exposure as an exposure to a particular client or a group of connected clients of more than $10 \%$ of own funds. The limit of large exposures was set to $25 \%$ of own funds (20\% for intragroup credits of which the bank or the credit institutions is part).

Regarding deposit protection schemes, Directive 94/19 introduced compulsory membership of such schemes for all credit institutions operating in the common market. Interestingly, there is considerable margin of discretion in the hands of member states determining whether such schemes should be publicly or privately organised.

Rules on the annual and consolidated accounts of banks were enacted by virtue of Directive 86/635 and,transparency and disclosure requirements of foreign branches were introduced through Directive 89/117. Moreover, in line with the consolidated accounts directive, supervision of banking and credit institutions on a consolidated basis was introduced. The banking sector often operates under complex group and control structures and, since 1983, legislation has been introduced to harmonise supervision of banking groups on a consolidated basis (Directive 92/30), initially on the proviso that the parent undertaking was a credit institution or a bank itself.

Supervision at a group level, with particular reference to solvency and risk exposure, was hindered by the relevant provisions of the 1983 directive, which excluded its application from groups controlled through holdings or non-financial institutions. The latter situation was changed by virtue of Directive 92/30, which consolidates supervision to groups controlled through financial holding companies and to groups where the parent undertaking is neither a credit nor a financial institution, but the group as a whole contains at least one banking or credit institution. The consolidated supervision directive follows a principle similar to the home control approach found in the banking co-ordination directives. In terms of competence, by mutual agreement between the relevant national authorities, consolidated supervision should be exercised by the authorities in the member state in which the group concentrates most of its activities. Such a principle could produce extra-territorial effects to the extent that consolidated supervision in non-member states would be achievable.

Another initiative in the banking sector was the adoption of legislation concerning common rules for consumer credit operations. Two directives have been adopted, the first being Directive 87/102, as amended by Directive 90/88 (OJ 1990 L61/14). It is worth noting that freedom of establishment and the freedom to provide services across frontiers also extends to mortgage credit. This will allow the various forms of credit available from national institutions that specialise in this area to be marketed throughout the Community. Finally, action was 
needed to prevent disreputable operators from taking advantage of the opening up of the banking and financial markets to exploit potential loopholes in the supervisory arrangements. The outcome was the adoption in 1991 of a directive aimed at preventing the use of financial institutions to launder the proceeds of criminal activities (Directive 91/308).

\section{Integrated payment systems}

Complementing the integration of the banking sector, the creation of integrated payment systems has been pursued by European institutions which have reiterated the importance of rapid and simple process of payments within the EU. Modern technology and, to a large extent, the results of the integration process in the banking sector have resulted in simplifying intraEU cross-border payments by means of electronic transfer between banks, by cheque or by payment card. Despite the effort which has been invested in creating a single market for banking services, non-tariff barriers still exist in cross-border payments. Transfers of small sums by individuals and businesses from one member state to another has been considered a complicated, expensive and slow exercise.

The European Commission has taken radical steps in improving a uniform payments system. A 1987 recommendation incorporating a code of conduct for relations between banks and retailers with regard to electronic fund transfers as a result of sales transactions envisages the creation of a unobstructed payments system for businesses, particularly small and medium sized enterprises which engage in cross-border trade. The code provides for prompt transfers and addresses the issue of delays in payments as a serious threat to the viability of small companies.

The Commission, in its 1988 recommendation setting out minimum terms and conditions for the protection of the holders of payment cards, has provided for minimum standards for consumers using credit and payment cards. Credit cards as a method of payment have been increasingly utilised by European consumers and the need for protection against fraud is pressing. A 1990 recommendation dealing with bank transfers, in particular with the information to be given to the customer, the time transfers should take and the possibilities of redress in the event of complaint, completes the picture of an exercise aimed at the establishment of a uniform payments system in Europe.

\section{Future improvements to banking}

In 1990 the Commission published a discussion paper on possible improvements to the integration of the banking sector, which has been looked into by two advisory groups set up in 1991 (one representing banks and central banks, the other bringing together various users). Most of the suggested improvements can be achieved through self-regulation or other voluntary action by the banking industry, although a few areas remain where legislation may be necessary or more effective.

In particular, the advisory groups have suggested that improvements should produce clear benefits for users of payment systems. Also, customers should be given clear information on the various ways of making a payment in or to another member state and the costs involved (including exchange costs). There should be no hidden charges for individuals when exchanging cash at banks or bureaux de change for foreign currency. Furthermore, new legislation should aim at encouraging banks and payment system providers to make payment instruments increasingly inter-operable and to link the payment and clearing systems of different member states.
A European banking standards committee (EBSC) is fully operational since 1993. It was established by the three European Credit Associations (the European Banking Federation, the European Savings Bank Group and the Association of Cooperative Banks of the European Community). The EBSC has an advisory but influential role in setting strict standards for the banking sector of the EU. Its agenda includes certain legal aspects of payment systems which need to be harmonised. Priority has been given to the harmonisation of legal regimes covering payment cards, cross-border transfers, electronic data interchange, securities and cryptographic security.

\section{THE INSURANCE SECTOR}

Freedom of establishment for insurance companies was introduced in the 1970s by the first EC directives on non-life insurance and life assurance (Directives 73/239 and 79/267 respectively). Motor insurance directives were also adopted, abolishing frontier checks on international insurance cards (green cards) and reducing differences in compulsory third-party insurance cover (Directives 72/166 and 84/5 respectively).

\section{THE MOTOR VEHICLE INSURANCE DIRECTIVES}

Directive $72 / 166$ on the approximation of the laws of member states relating to insurance against civil liability in respect of the use of motor vehicles, and to the enforcement of the obligation to insure against such liability (OJ 1972, L166/77)

Directive $84 / 5$ on the approximation of the laws of the member states relating to insurance against civil liability in respect of the use of motor vehicles (OJ 1984 L8/77)

Directive $90 / 232$ on the approximation of the laws of the member states relating to insurance against civil liability in respect of the use of motor vehicles (OJ 1990 L129/33)

However, progress towards ensuring full freedom to provide services in the insurance sector was not satisfactory. In 1988, the Council adopted a second directive on non-life insurance to secure some harmonisation of national laws in this area (Directive 88/357). In particular, a wide range of freedom to provide services in connection with major risks in the industrial, commercial and transport sectors as well as free access to the Community market for large policyholders were set out. The same principle of freedom to provide services (implying free access for policyholders to the whole Community market) also applies to life assurance and motor insurance, and in 1990 the Council adopted directives on them as well (Directives 90/619 and 90/232 respectively).

\section{Cross-border insurance}

The life and non-life assurance directives provided for a broad framework of freedom to provide services and hence free access to the whole Community market for customers to take out policies in other Community member states, either directly or through an intermediary. Consumer protection was guaranteed by a rule under which the law of the policyholder's home country would normally apply. The operational framework for insurance services on non-life insurance and life assurance has established:

- a single licence issued in the country where the insurance company is based, along the lines of the system already adopted for banking;

- greater freedom for the insurer in drawing up new contracts;

- common rules on the assets which insurers are required to set aside to meet their commitments; 
- provisions to ensure that inspectors from the country of a policyholder will be able to secure adequate protection for that policyholder and to monitor compliance with any rules of general interest in force in the policyholder's country;

- full information for policyholders about their insurer and the content of their policy.

The first non-life directive and first life directive achieved four objectives:

(1) They provided common conditions for authorisation of insurance companies enabling EU insurers wishing to operate in other EU states to set up branches or agencies in those states without being subject to more onerous restrictions than their local competitors.

(2) They laid down common solvency regulations.

(3) They established a minimum guarantee fund: non-life generally - ECU 400,000 and life - ECU 800,000.

(4) They established a system whereby each state became responsible for ensuring that an authorised insurer has sufficient technical reserves.

\section{NON-LIFE INSURANCE DIRECTIVES}

Directive $64 / 225$ on the abolition of restrictions on freedom of establishment and freedom to provide services in respect of reinsurance and retrocession (OJ 1963-64, Eng. Spec. Ed., p. 131)

Directive $73 / 239$ on the co-ordination of laws, regulations and administrative provisions relating to the taking-up and pursuit of the business of direct insurance other than life assurance (OJ 1973 L228/3)

Directive $73 / 240$ abolishing restrictions on freedom of establishment in the business of direct insurance other than life assurance (OJ 1973 L228/20)

Directive $78 / 473$ on the co-ordination of laws, regulations and administrative provisions relating to Community co-insurance (OJ 1978 L151/25)

Directive $87 / 344$ on the co-ordination of laws, regulations and administrative provisions relating to legal expenses insurance (OJ 1987 L185/77)

Directive $88 / 357$ on the co-ordination of laws, regulations and administrative provisions relating to direct insurance other than life assurance and laying down provisions to facilitate the effective exercise of freedom to provide services, amending Directive 73/239 (OJ 1988 L172/1)

Directive $92 / 49$ on the co-ordination of laws, regulations and administrative provisions relating to direct insurance other than life assurance and amending Directives 73/239 and 88/357 (third non-life insurance directive) (OJ 1992 L228/1)

It should also be mentioned that the first life directive restricted composites from opening new branches or agencies to transact life business in EU states when they were not already established in 1979

The second non-life directive accomplished three objectives alongside the provisions of the first non-life directive:

(1) It established freedom for insurers to supply non-life insurance for large risks across frontiers without the need for authorisation in the host state.

(2) It provided that the notification of policy conditions, premium rates and documents relating to large risks would be allowed on a non-systematic basis only.
(3) It provided rules governing choice of law applicable to insurance contracts in order, in particular, to favour the consumer.

The second life directive introduced freedom of services for life insurance companies. In addition, the host country cannot require authorisation for contracts taken out on the consumer's own initiative. The 'own initiative' test will be applied by reference to public policy in the host country.

The third non-life (Directive 92/49) and the third life directive (Directive 92/96) expanded the principles of their predecessors, complementing the framework of freedom to provide life and non-life insurance services within the common market. In particular, the third life and non-life insurance directives have been influenced by the relevant directives in the banking sector.

The new regime established home country control and mutual recognition, along the lines of the banking directives. It provided a formal framework of co-operation between the supervisory authorities of member states and obliged the home country to verify the suitability of the insurers' management and controllers. The directives also provided for a common basis for calculation of technical reserves and a system to limit the control of policy conditions or premium rates by home or host country. Finally, they lifted the restrictions on new authorisations for composite insurers.

\section{Liberalisation}

The most important element still to come is the liberalisation of insurance services for mass risks. Although the second non-life directive has released the large risk insurance services from host country control, mass risk insurance are still subject to the restrictions of the state where the risk or the policyholder is located. It should be mentioned here that 'large' risk insurance services cover two main categories of insurance: the first is marine, aviation or transit insurance, whereas the second relates to fire, property damage, general liability or financial loss insurance for a large policyholder (principally those having more than 250 employees and annual turnover in excess of ECU12m).

The third life and non-life directives explicitly exclude reinsurance (insurance of insurers). Due to the fact that reinsurance has largely international dimensions and effects and encroaches little on the consumer, there were generally few national regulations. Therefore there was little difficulty in agreeing the reinsurance and retrocession directive which abolished restrictions on the freedom of establishment and freedom to provide reinsurance and retrocession services (Directive 64/225). However it only established equality of treatment in local regulations. Hence reinsurers will be subject to restrictions not applying to their associated companies writing direct business.

\section{Harmonisation}

Insurance companies are free to provide services in different countries of the EU and the Council wished to ensure openness and transparency in their operations. Accordingly, in 1991 it adopted a directive on the harmonisation of the annual accounts of insurance companies to facilitate monitoring and comparison. Also in 1991 a recommendation on insurance intermediaries (such as brokers and agents) was adopted by the Commission. This had the twofold aim of setting a minimum level of qualifications and of clarifying the distinction between dependent and independent intermediaries. Again in 1991, the Commission 
sent the Council a proposal for a directive on the freedom of pension funds to manage and invest their assets.

The motor insurance directives set out to secure wide freedom for major policyholders. But, in the interests of insured parties and accident victims, insurers providing services outside their home country must designate representatives responsible for settling claims in the country or countries where they operate. Representatives should normally be insurance companies themselves or intermediaries covered by the law of the particular member state where an insurance claim is made. The reason for such provision is to ensure access to justice for claimers or victims where an out-of-court settlement is not possible.

\section{THE LIFE ASSURANCE DIRECTIVES}

Directive $79 / 267$ on the co-ordination of laws, regulations and administrative provisions relating to the taking up and pursuit of the business of direct life assurance (OJ 1979 L63/1)

Directive $90 / 619$ on the co-ordination of laws, regulations and administrative provisions relating to direct life assurance, laying down provisions to facilitate the effective exercise of freedom to provide services and amending Directive 79/267 (OJ 1990 L330/50)

Directive $92 / 96$ on the co-ordination of laws, regulations and administrative provisions relating to direct life assurance and amending Directives 79/267 and 90/619 (third life assurance directive) (OJ 1992 L360/1)

Directive $77 / 92$ on measures to facilitate the effective exercise of freedom of establishment and freedom to provide services in respect of the activities of insurance agents and brokers (ex ISIC Group 630) and, in particular, transitional measures in respect of those activities (OJ 1977 L26/14)

Directive $91 / 674$ on the annual accounts and consolidated accounts of insurance undertakings (OJ 1991 L374/7)

Directive 91/675 setting up an Insurance Committee (OJ 1991 L374/32)

\section{STOCK EXCHANGE AND SECURITIES MARKETS}

The Commission's overall objective is to create a unified securities market enabling issuers to raise capital on a Community-wide basis, allowing intermediaries to offer services and create branches in other member states as easily as in their own, and offering investors a wide range of competing investment products to choose from. A number of directives have been adopted towards this end. The three stock exchange directives, although adopted at different times, contributed towards constructing a single package with the same implementation deadline for all three.

The first directive, adopted in 1979 (Directive 79/279), coordinated the conditions for the admission of securities to official stock exchange listing (e.g. minimum size, minimum period of existence, distribution of securities among the public etc.) and imposed permanent obligations on issuers. In particular they must publish information on any new developments likely to have a substantial effect on the price of their securities.

The second directive, dating from 1980 (Directive 80/390), dealt with stock exchange admission prospectuses and $\mathrm{CO}^{-}$ ordinated the information to be disclosed so as to enable investors to make an informed assessment of the assets and liabilities, financial position, profits and losses, and prospects of the issuer and of the rights attaching to the securities.

The third directive, adopted in 1982 (Directive 82/121), required listed companies to publish half-yearly reports giving turnover and profit-and-loss figures for the first six months of the financial year.

\section{Integration}

In addition to the above package, a number of directives have been enacted with a view to complementing the process of integrating the securities and stock exchanges markets. In 1985 there was a directive on open-ended undertakings for collective investment in transferable securities (UCITS), which include unit trusts and investment funds (Directive 85/611). This laid down common rules, with provision for home country control. Once a UCIT has been licensed in its home country, it is able to market its units in other member states without having to reapply for a licence each time, since all the member states recognise the home country's rules and controls.

Mutual recognition on stock exchange listing prospectuses was provided by the 1987 directive, amending the directive of 1980 (Directive 87/345). A prospectus approved in the home country no longer needs separate approval in others and can be issued without any change in content (except, of course, that it may have to be translated). A 1989 directive allows issuers to use the prospectus approved in their home country when securities are first offered simultaneously to investors in other member states (Directive 89/298). The standard of disclosure must be at least the same as that required by the 1980 directive. A 1990 directive further amended the 1980 legislation to allow issuers to use a single prospectus, approved in their home country, both for public offers and for admission to stock exchange listing anywhere in the Community (Directive 90/211).

In 1989, a directive on insider trading required all the member states to introduce similar rules, so as to safeguard the smooth operation of the unified market and ensure investor confidence in it (Directive 89/592). A 1988 directive dealt with the information to be published when major holdings in listed companies are acquired or disposed of (Directive 88/627). Anyone buying or selling a major shareholding must notify the company in question of their new number of voting rights if any of the thresholds laid down in the directive are exceeded. The company must then publish the information in compliance with its obligations under the 1979 directive (Directive 79/279).

Two further directives complete the picture of an integrated securities market. An investment services directive aims to bring in a 'European passport' for anyone wishing to carry out investment business in securities and related instruments, subject to home country authorisation, regulation and supervision (Directive 93/22). It extends the right to provide such services (already enjoyed by banks under the second banking directive) to non-bank firms and will allow all investment firms, banks and non-bank companies, to have access to stock exchange membership in all the member states and to set up branches or subsidiaries there.

Also, a directive on capital adequacy will require investment firms to meet certain conditions designed to ensure that they have sufficient capital to cover a range of risks, although it does not set a binding minimum level of financial resources (Directive 93/6). The intention is to ensure adequate investor protection and rough equivalence between bank and non-bank investment firms, while enabling the Community's financial centres to remain competitive compared to rival financial markets outside. 


\section{CONCLUSIONS}

The completion of the single market in financial services marks the culmination of a process that has been under way for some time. Highly integrated markets already exist in reinsurance and transport insurance, while many banks have branches in the EU's main financial centres and a large number of securities are listed on the stock exchanges of more than one member country. In the past, however, national regulations, imposed mainly for prudential reasons, have hampered financial institutions in their attempts to set up in other member states or offer services there. Open markets, free competition and cost efficiency have not always proved attainable.

Despite its undoubtedly crucial role, the liberalisation of capital movements is not sufficient in itself to ensure effective integration of the financial services markets. Its function should be considered within the framework of the freedom of establishment and the freedom to provide services. Even after the lifting of all restrictions on capital movements, inconsistent national regulations could pose barriers restricting freedom of establishment and hampering free trade in financial services. Without common rules for the supervision of financial institutions, business would tend to migrate to centres where supervision is most lax.

There also have to be equivalent standards for protection of investors. Based on the basic principles of the Treaty and on the legislation already in place, the white paper set out a general strategy for achieving the Community's objectives, involving;

(1) the harmonisation of basic standards for supervising financial institutions and protecting investors, depositors and consumers;

(2) mutual recognition by the supervisory authorities in the member states of the way in which they each apply those standards;

(3) based on these first two elements, 'home country control and supervision' of financial institutions (i.e. by the country where they are based) covering all their operations throughout the Community, whether through branches or in direct services across frontiers.

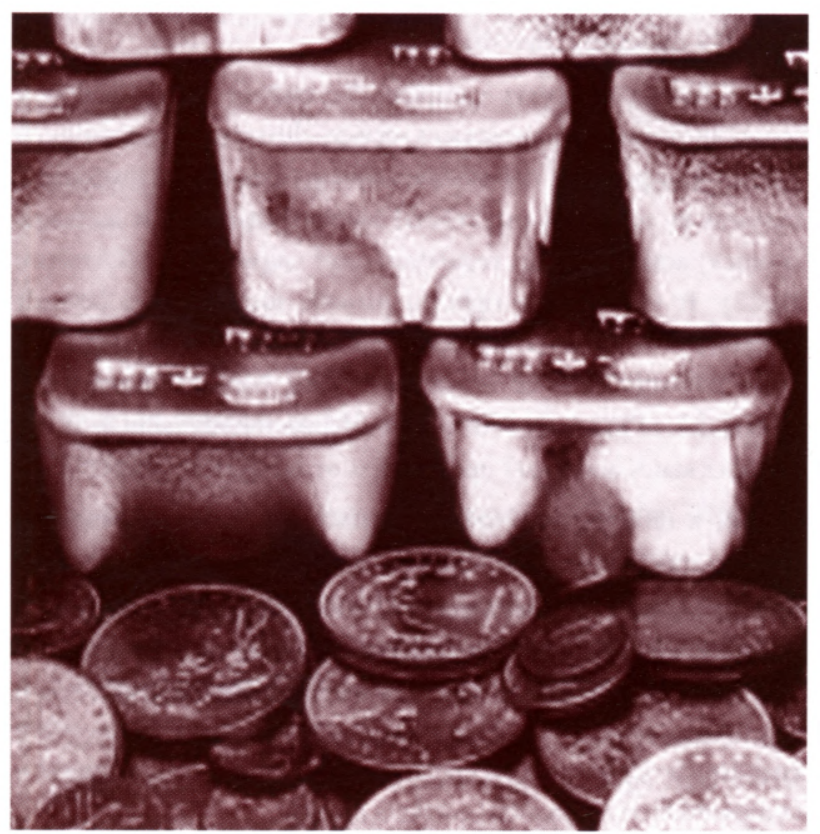

THE STOCK EXCHANGE AND SECURITIES MARKETS DIRECTIVES

Directive $79 / 279$ co-ordinating the conditions for the admission of securities to official stock exchange listing (OJ 1979 L66/21)

Directive $80 / 390$ co-ordinating the requirements for the drawing up, scrutiny and distribution of the listing particulars to be published for the admission of securities to official stock exchange listing (OJ 1980 L100/1)

Directive $82 / 121$ on information to be published on a regular basis by companies the shares of which have been admitted to official stockexchange listing (OJ 1982 L48/26)

Directive $87 / 345$ amending Directive $80 / 390$ co-ordinating the requirements for the drawing-up, scrutiny and distribution of the listing particulars to be published for the admission of securities to official stock exchange listing (OJ 1987 L185/81)

Directive $88 / 627$ on the information to be published when a major holding in a listed company is acquired or disposed of (OJ 1988 L.348/62)

Directive $89 / 298$ co-ordinating the requirements for the drawing-up, scrutiny and distribution of the prospectus to be published when transferable securities are offered to the public (OJ 1989 L124/8)

Directive $89 / 592$ co-ordinating regulations on insider dealing (OJ 1989 L334/30)

Directive 90/211 amending Directive 80/390 in respect of the mutual recognition of public-offer prospectuses as stock-exchange listing particulars (OJ 1990 L112/24)

Directive $85 / 611$ on the co-ordination of laws, regulations and administrative provisions relating to undertakings for collective investment in transferable securities (UCITS) (OJ 1985 L375/3)

Directive $93 / 6$ on the capital adequacy of investments firms and credit institutions (OJ 1993 L141/1)

Directive 93/22 on investment services in the securities field (OJ 1993 L141/27)

As far as banking operations and dealings in securities are concerned, the key element of the system is a single licence issued by the member state where an institution is based, allowing it to market services in other member countries either through branches or directly across frontiers, provided it is allowed to market those same services in its home country. In the insurance sector, on the other hand, supervisory control will be divided for a time between the member state where a company is based and those where it has agencies or branches, before the system eventually switches over to the same pattern as for other financial institutions.

\section{Christopher Bovis}

Visiting Professor, Queen's University of Belfast

Deputy Director, Institute of European Law, Hull University 